1859.] HOLL-THINNING-OVT OF THE SECONDARY ROCKS.

Fig. 5. Under view of the same skull. [All the figures are of the natural size: the original is in the British Museum; the letters and figures are explained in the text.]

\title{
PLATE III.
}

Fig. 1. Side view of the fore end of the skull of Cynochampsa laniarius.

Fig. 2. Front view of the same.

Fig. 3. Upper view of the same.

Fig. 4. Under view of the same, showing the bodies and pulp-cavities of the fractured upper and lower canines, nat. size. [Original in the British Museum.]

Fig. 5. Under view of part of the skull, with the hyoidean arch and appendages, of Oudenodon, nat. size. [The original is in the British Museum; the letters and figures are explained in the text.]

2. On the Sodth-easteriy Atrendation of the Lower Secondart Formations of England ; and the probable Depth of the CoalMEASURES under OxFORDSHIRE and NoRTHAMPTONSHIRE.

By Edward Hrul, Esq., A.B., F.G.S., of the Geological Survey of Great Britain.

\section{[Plate IV.]}

\section{Contents.}

\$ 1. Introductory remarks on Mr. R. Godwin-Austen's theory, and on the Formations of the Franco-Belgian Coal-field.

\$ 2. Distribution of the Lower Permian Rocks of Central England. $A$. Shore of the Lower Permian basin.

8 3. South-easterly Attenuation of the Lower Secondary Rocks :-

1. The Trias.

$A$. Bunter Sandstone.

$B$. Lower Keuper Sandstone.

C. Red Marl.

2. Claims of the Trias to more consideration from Geologists.

3. The Lias; connexion of its three members, and their range and limit.

$A$. Lower Lias.

B. Marlstone.

C. Upper Lias.

4. The Inferior Oolite; its attenuation.

5. The Fuller's Earth.

6. The Great Oolite ; its Lower and Upper Zones, and their comparative range.

8 4. Extension of the Coal-measures under Oxfordshire and Northamptonshire, from Warwickshire to the Valley of the Thames.

\$ 5. Physical Geography of the Trias.

$A$. Evidence of land in the North Atlantic area during the Newer Palæozoic and Older Secondary Periods.

$B$. Subaërial conditions in the British area during the formation of the Muschelkalk of Germany.

C. Unconformity of the Bunter and Keuper Formations.

$D$. Causes of Variations in the Persistency of Strata.

8 6. Probable South-easterly Attenuation of the Carboniferous Series.

\$7. General Conclusions.

\$ 1. Introduction.-The present is, perhaps, a fitting occasion for submitting to the notice of the Society the following ideas regarding the extension of the Lower Secondary Rocks in the direction of the 
Thames Valley, as the focus of my remarks lies in the district of Oxfordshire, with the geological structure of which our learned President is so intimately acquainted.

My way has been, to a certain extent, prepared by the elaborate Essay " On the possible Extension of the Coal-measures beneath the South-eastern Part of England," by Mr. Godwin-Austen, communicated to this Society*. This essay and the researches of Mr. Prestwich have excited much interest regarding the rocks which underlie the Cretaceous and Oolitic formations. It is with the object of throwing some further light on this important subject that the following observations and deductions have been drawn up.

It is almost unnecessary to reiterate here what is now so fully understood, from the researches of D'Archiac, Rozet, Prestwich, and especially of Godwin-Austen, that along the line of the FrancoBelgian Coal-field the Cretaccous and Nummulitic rocks repose on the highly inclined edges of the Palæozoic Rocks without the intervention of those of the Lower Secondary periods. In the district of the Bas-Boulonnais similar phænomena are observable; but we learn from the memoir of MI. Rozet that strata referred to the Great Oolite abut against the northern flank of the Palæozoic range and rest on a bed of Carboniferous Rocks $†$.

Adopting the theory of Mr. Austen regarding the extension of the Palæozoic axis of clevation under the Thames Valley, I do not, however, consider that the entire absence of all the intervening formations between the Great Oolite and the Coal-measures is to be attributed altogether to the presence of this old coast-line, but to other causes to be hereafter stated. I shall endeavour to show that all these formations decrease in thickness, as they approach the south-east of England, from the failure of sediment, in the manner of deposits forming at the mouths of large rivers.

I also propose to inquire whether the Uppermost Palæozoic rocks, namely the Coal-measures and Permian deposits, are regulated in their distribution upon a similar physical plan; or whether they may not have a much wider range, and extend into districts where many of the more recent formations cease.

Lastly, whether there are not reasons for concluding that under certain districts of Oxford and Northampton the Coal-measures lie at available depths below the surface, owing to the thinning away of the Lower Secondary rocks.

§ 2. Distribution of the Lower Permian Beds of Central England. -Upon comparing the Lower Secondary with the Uppermost Palacozoic formations, we discover a very marked difference in their distributions. We find the Bunter-Schicfer and Zechstein appearing only in the north-eastern districts of England, and the Rothe-todteliegende confined principally to the central counties and Salop; while the Trias is most fully developed towards the north-west.

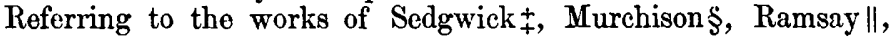

* Quart. Journ. Geol. Soc. vol. xi. p. 533.

+ Rozet, 'Description Géognostique du Bassin du Bas-Boulonnais.'

+ Trans. Geol. Soc. 2nd Series, vol. iii. \$ 'Siluria,' new edit.

॥ Quart. Journ. Geol. Soc. vol. xi. p. 185. 
and other authors for descriptions of these rocks, I proceed to make some observations on the topographical distribution of the Lower Permian rocks or Rothe-todte-liegende.

The red and purple sandstones, marls, and brecciated conglomerates of which the Lower Permian formation is composed, attain their greatest development along a band of country stretching from west to east, including parts of the counties of Salop, Worcester, Stafford, and Warwick; while in the north-west districts of Cheshire, where the Trias has been deposited in great force, the Permian rocks are but sparingly represented.

I beg to call particular attention to this fact, because it shows how great has been the break in the order of succession, in consequence of considerable changes in the distribution of land and sea between the Palæozoic and Mesozoic epochs.

From sections published by the Geological Survey, traversing the Permian rocks of Enville in Salop, the thickness of the formation has been found not less than 1700 feet*. On both sides of the South Staffordshire Coal-field, the thickness is probably not less than this; and $\mathrm{Mr}$. Howell's estimate of the maximum depth of the large mass of these red rocks in the neighbourhood of Coventry is 1800 feet $\uparrow$. The north-eastern limit of the formation appears to skirt the southern edge of the Leicestershire Coal-field ; thence trending along a northwest line, it crosses the centre of the North Staffordshire Coal-field; from thence it may be traced at intervals northward into Scotland + . Its westerly limit is the Denbighshire Coal-field. Its southern limit is not so easily defined, and this fact forms a most serious question in speculating upon the descending series of rocks which underlie the districts of Oxfordshire and Northamptonshire. It would be a subject for small congratulation if, on sinking for coal orer these districts, it should be found that while the Lower Mesozoic rocks had become comparatively thin, the Permian formation existed in great force beneath. As Mr. Godwin-Austen has truly stated, such questions, in the absence of direct experiment, can be solved only by a restoration of the land-surfaces and coasts of the period; and, we may add, by a knowledge of the sources from which the sedimentary materials have been derived.

A. Distribution of Land and Sea at the Lower Permian Period.There is the strongest evidence for believing that there was a much larger extent of land-surface during the formation of the Permian rocks than during that of the Trias. Professor Ramsay $\S$ has demonstrated with, it appears to me, great probability, that the breccias which occupy a central position in the Rothe-liegende of Salop and Worcester are the ice-drifted débris of sub-aërial regions of the Longmynd and adjacent Silurian ranges. The Alberbury breccia $\|$

* Horizontal Sections, Sheet 53.

+ Horizontal Sections of the Geological Survey, Sheet 51.

\$ See Mr. Binney, " On the Permian beds of the North-west of England," Mem. Lit. \& Phil. Soc. Manchester, 1855. Also Prof.Sedgwick, Trans. Geol.Soc. 2 ser.vol.iv.

$\S$ Quart. Journ. Geol. Soc. vol. xi. p. 185.

II See 'Silurian System,' p. 48-49, where the author traces the origin of some of the fragments of the breccia to certain freshwater limestones of the Coal-measures.

VOL. XVI.-PART I. 
is certainly the remnant of a shingle-beach, formed at the base of the Carboniferous Limestone ridge at the southern termination of the Denbighshire Coal-field; and the limestone-conglomerates which we find at intervals (in a zone lower than the trappoid breccia) over the whole of the Midland Counties are representatives of this shingle-beach. It is also to be noticed, that there is a strong lithological resemblance between the Old Red Sandstone of Herefordshire and Salop and the neighbouring Permian rocks; and I have long entertained the idea that the Lower Permian of the western districts is to a great extent a re-formation of the Old Red Sandstone, which once had a more extended range than at present, as is testified by the outlying masses capping the Ludlow rocks of Salop and Radnor. It would, therefore, seem that at the commencement of the Permian age the coast-line extended from the Abberley range northwards along a line nearly corresponding to the present limits of the Lower Carboniferous and Silurian rocks of Wales and Salop. From the Flintshire Coal-field eastward to that of North Staffordshire, there probably existed a channel deepening towards the centre, and forming a basin for the Permian deposits in the direction of Lancashire. The axis of elevation of the Carboniferous range of the Penine chain continued along the borders of Charnwood Forest; and, considerably east of the present edge of the Warwickshire Coalfield, formed the land towards the north-east; and upon the prolongation of this barrier, which seems to stretch in a E.S.E. direction, depends the existence of the Lower Permian rocks under Northamptonshire*.

Considering the grcat thickness of the Permian rocks in Warwickshire, it is improbable that they have been formed altogether of the Older Palæozoic rocks of Wales and Salop. The bed of calcareous conglomerate, which occupies a nearly central position, is composed of pebbles of Carboniferous Limestone and Silurian rocks, and indicates the proximity of land. The rocks of Charnwood Forest may possibly be a portion of the western prolongation of that Palæozoic dry land which, according to Mr. Godwin-Austen, occupied the German Ocean at this period. If so, the Lower Permian strata would appear to have been accumulated within a comparatively narrow channel or longitudinal basin, the axis of which stretched from the valley of the Eden towards the south-east, in which direction the channel became wider. The western border trended due south towards the Bristol Channel; and the eastern probably curved round towards the German Oceant. We cannot with cer-

* It should be here stated that, as the Warwickshire Coal-field has been thrown up along its north-east edge by a fault of considerable magnitude, there is every probability that both Permian rocks and Coal-measures exist to the N.E. of this fault, extending to the barrier, which may be considered as indicated by the trappean bosses of Stoney Stanton.

$\dagger$ Both Mr. Godwin-Austen and Mr. Sorby, from independent data, have shown the probability of land having existed during a portion of the Upper Paløozoic and Mesozoic periods over the area occupied by the German Ocean; and in this view the author concurs, from considerations connected with the distribution of the Permian rocks. 
tainty define the southern limit of the formation under the districts of Oxfordshire and Northamptonshire ; but, recollecting the absence of these rocks below the Chalk near London, Boulogne, and the FrancoBelgian Coal-field, it is probable that they become attenuated southwardly from Warwickshire. From considerations founded on currentstructures, Mr. Sorby seems to have arrived at a similar conclusion.

\section{§ 3. South-Easterly Attenuation of the Lower Secondary Rocks.}

1. The Trias.-A. Bunter Sandstone-Our inquiries commence with this formation, which introduces the Mesozoic Series, and rests unconformably on all the rocks of Palæozoic age. Attaining its highest derelopment towards the north-west, it composes the plains of Cheshire and Lancashire ; it fills the beds of old Palæozoic valleys, as those of the Eden, the Clewyd, and Belfast Lough; and from its position along the sea-coasts of Ireland, the Isle of Man, North Wales, Lancashire, and Cumberland, it probably forms a large portion of the bed of the Irish Sea.

It is, however, only recently, since the detailed examination carried out by the officers of the Geological Survey, that anything like a just estimate of the stratigraphical importance of this formation has been arrived at. It has been classified into three subdivisions, sufficiently marked to enable us to compute the depth of the formation in any given district, and such as allows us in the present inquiry to arrive at definite results.

From a section across the plain of Chester, and Delamere Forest, we obtain the following vertical measurement of these subdivisions in this district*.

\section{Bunter Sandstone, Cheshire. North-west District.}

3. Upper mottled Sandstone ....... . 700 ft.

2. Conglomerate-beds. . . . . . . . . 750

1. Lower mottled Sandstone ........700

Total thickness .... $\overline{2150}$

The general succession of the Trias in North-west Cheshire is shown in Pl. IV. fig. 2.

A few miles further south, at Holt, another section gives the thickness of the Bunter Sandstone at 1600 feet; and a third, across Bridgenorth, in Salop, shows nearly the same result.

Now, whenever we follow these beds eastward, from their furthest western outcrop, we invariably find that they decrease in thickness; some of the subdivisions more rapidly than others. 'In the counties of Derby, Stafford, Leicester, and Warwick, the 1st and 3rd subdivisions are generally absent, or only sparingly represented. The Conglomerate-beds predominate frequently where the other subdivisions have disappeared; but when we cross to the eastern borders of the Leicestershire and Warwickshire Coal-fields, this most constant subdivision thins away. We find the Lower Keuper Sandstone resting directly on the Coal-measures at Ashby, and

* Horizon. Sect. of the Geol. Survey, Sheet 43. 
Coleorton in Leicestershire, and on the Permian Rocks further south at Warwick,- - the whole of the Bunter Sandstone having consequently thinned out.

B. Keuper.-We now proceed to trace the range of the Keuper, under its two principal subdivisions-the Lower Keuper Sandstone, and Red Marl. The former of these is frequently introduced by a band of hard calcareous breccia, with laminated red shales, which is succeeded by evenly bedded ripple-marked sandstones and marls (called "Waterstones" by Mr. Ormerod*). In Cheshire and Lancashire, the Lower Keuper Sandstone reaches a thickness of 450 feet, forming the scarped ranges of the Runcorn, Delamere, and Peckforton Hills. These beds have been traced on the maps of the Geological Survey over the western and central counties; and, as a general rule, they are found to decrease in thickness in proportion as they approach the South-eastern counties. Around the skirts of the Leicestershire Coal-field this subdivision has a general thickness of 200 feet; and over the centre and the eastern side it rests immediately on the Coal-measures, without the intervention of the Bunter Sandstone. The district around Warwick is that along which it becomes most rapidily attenuated, and where it is on the point of being ultimately concealed by the Red Marl. As in the case of the Leicestershire Coal-field, the Lower Keuper Sandstone is here the most ancient member of the Trias, and I am informed by Mr. Howell, of the Geological Survey, that its thickness may be estimated at not more than 150 feet.

Comparing, then, the thickness of this subformation where it is visible for the last time towards the south-east with that which it assumes in West Cheshire, we find that it has decreased by twothirds in its extension from the one locality to the other; the horizontal distance being 85 miles. Now, if this decrease continues in the same proportion, the whole subformation ought to disappear several miles N.W. of Oxford † (Plate IV. figs. 2, 3, 4).

C. Red Marl.--The thickness of the Red Marl in Cheshire has been much under-estimated. From considerations connected with the depths of the salt-beds, Mr. Ormerod estimates it at more than 700 feet $\ddagger$; but I feel sure he will allow that these data can scarcely afford even an approximate computation, as we are still uncertain of the nature of the beds which underlie the salt-rocks, and of the position of those through which the shafts have been sunk at Northwich.

A very perfect section along the banks of a brook (without a name in the Ordnance Map), three miles south of Malpas, although it does not extend nearly to the top of the formation, shows the Red Marl to be of much greater thickness than it is generally considered. The beds, consisting of fine laminated red and grey shales, may be

* Quart. Journ. Geol. Soc. vol. iv.

+ Maps of the Geol. Survey, 53 N.W. -63 S.W.

+ Quart. Journ. Geol. Soc. vol. iv. p. 288 . For local descriptions of the Triassic Rocks of Cheshire and Lancashire, see the Memoirs of Messrs. Binney, Ormerod, J. Cunningham, and R. Rawlinson in the Journal of the Geological Society. 
1859.] HULL-THINNING-OUT OF THE SECONDARY BOCKS.

traced for a distance of two miles, with an average dip of $15^{\circ}$ to the S.E. From this section alone a thickness of 2300 feet may be estimated; and, judging from the interval between the point where the section ceases and the lias boundary at Whitchurch, the thickness must be mụch greater. From various comparisons it appears probable that from 3000 to 3500 feet is not an overestimate. Now, in Staffordshire, Leicestershire, and the central districts generally, the Red Marl does not exceed a thickness of 600 or 700 feet, showing a great decrease towards the S.E. from Cheshire (Plate IV. figs. 2, 3).

The direction of maximum attenuation, however, is along a line drawn S.E. from the Estuary of the Dee, and passing near Nantwich, Stafford, and Warwick, beyond which the formation is lost below the Lias. If we put down as the thickness at each of these places respectively, 3000,700 , and 400 feet, we shall have probably a just conception of the rapid thinning-out of these beds; and it therefore appears by no means improbable that even this great argillaceous series is extremely thin, or altogether absent, in Oxfordshire and Northamptonshire.

If, then, we compare the section of the Trias, as it occurs in Cheshire and East Warwick, we find the following result:-

$$
\begin{aligned}
& \text { feet. } \\
& \text { Cheshire } \ldots \ldots\left\{\begin{array}{l}
\text { Red Marl } \ldots \ldots \ldots \ldots \ldots \ldots . .3000 \\
\text { Lower Keuper Sandstone. . . } 450 \\
\text { Bunter Sandston } \ldots \ldots \ldots .2150
\end{array}\right. \\
& \text { Total ..... } \overline{\mathbf{5 6 0 0}} \\
& \text { East Warwickshire }\left\{\begin{array}{r}
\text { Red Marl . . . . . . . . . . 400 } \\
\text { Lower Keuper Sandstone . . . . 200 } \\
\text { Bunter Sandstone . . . . . absent } \\
\text { Total . . . } 600
\end{array}\right.
\end{aligned}
$$

In other words, the formation is ten times thicker in the former than in the latter county.

2. Claim of the Trias to Consideration.-A formation which attains so great a development deserves, I think, a larger share of attention than it has yet received from geologists. There are few groups which, in the almost entire absence of fossils, have so strongly stamped upon them the impressions of varying physical changes during their growth. We find in it stages which have been strongly influenced by current-action, and others of apparent tranquillity. We find shingle-beaches, some traceable to their coast-lines, and conglomerates which have been drifted from regions comparatively remote.

Its structure, however, presents phænomena of much interest to the physical geologist. It is frequently traversed by systems of faults, which, in the form of escarpments, ridges, and valleys, have left their marks in the configuration of the surface*; and no person

* In many districts of Cheshire, Salop, and Staffordshire, the co-ordinate lines of fracture, with their cross-fractures, may be very readily traced by the features 
who has visited the districts of Alton, Cheadle, and Trentham, or climbed the escarpments of the Hawkestone, Peckforton, and Runcorn ranges, can deny to the New Red Sandstone an amount of scenic power almost comparable with that of the Oolites of Gloucestershire.

3. Lias.-A. Lower Lias.-We have not, unfortunately, the same facilities for making comparisons of the development of the Lower Lias in the Western and Eastern Districts. With the exception of the outlier at Prees in Shropshire, and a newly discovered area of the same formation near Carlisle*, we have no districts of comparison; and, as these do not present us with the whole ascending series, they are useless for our purpose. I therefore propose to treat this formation by analogy. It must be allowed that there is a close connexion between the Lower, Middle, and Upper Lias formations. As far as we can judge, the strata are strictly conformable. There are no breaks greater than between different subdivisions of the Inferior Oolite. There is a generic community of the fauna; and the mineral characters of the series are repeated at intervals throughout. We are, therefore, justified in supposing that all the Liassic formations of central England have had their origin from the same sources and under similar physical conditions, and are therefore equally subject to attenuation when receding from those sources. If, therefore, it can be shown that there is a tendency on the part of the Marlstone and Upper Lias to thin away towards the south-east, and that this attenuation takes place within the range of actual observation, there will be strong grounds for inferring a similar propensity on the part of tho Lower Lias; at least, it is upon these grounds that I base the analogy. When we come to consider, in a subsequent part of this paper, how strong are the reasons for believing that all these formations have been derived from regions lying to the northwest of the British Islands, the analogy will be found to gain additional force.

B. Marlstone.-Let us now trace the Marlstone along its S.E. extension towards Oxford. At Bredon Hill (see Plate IV. fig. 1), a large outlier near the confluence of the Avon and Severn in North Gloucestershire, the Marlstone attains a thickness of 250 feet; probably the greatest known in this part of England. On the flanks of Ebrington Hill, the extreme northern termination of the Cotteswold Range, the thickness, as computed by Mr. Howell, is 150 feet †; at Leckhampton Hill, near Cheltenham, the thickness is 115 feet + , by accurate measurement, which is the average development of the formation along the whole of the Cotteswold Hills.

of the surface, by one who possesses a perfect knowledge of the succession of the beds. These faults admirably bear out the principles laid down by Mr. Hopkins of Cambridge, followed by Mr. Jukes and Professor Haughton.

* Recontly communicated to the Manchester Geological Society by Mr. Binney. See also Quart. Journ. Geol. Soc. vol. xv. p. 549.

+ "Geology of the Country around Cheltenham," Mom. Geol. Survey, 1857, p. 19. + Ihid. plate 2 . 
If we trace these beds towards the borders of Oxfordshire, along the Valley of the Evenlode, that is, in a direction E.S.E. from Bredon Hill, we find a marked diminution in the thickness. At Burford, Shipton, and Charlbury, the farthest points where the thickness of the Marlstone can be ascertained, we find it to have dwindled down to an average of 20 feet, or less than one-tenth of its amount at Bredon. If, therefore, this attenuation continues in nearly the same ratio, the formation cannot extend far beyond the city of Oxford. It is remarkable, however, that the "Upper Rockbed" shows far less disposition to thin out than the underlying sandy strata, which, in Gloucestershire form nine-tenths of the mass of the formation.

C. Upper Lias.-In the case of the Upper Lias Shale, the southeasterly attenuation is even more decided. Its thickness at Bredon Hill is nearly 400 feet*; but at Leckhampton Hill it reaches 230 feet, including a few beds of superimposed sands. From this point eastward the formation thins away; and at Stonesfield, in the Valley of the Evenlode, it may be said to have finally disappeared, being represented only by a band of shale four feet thick; the Inferior Oolite resting almost immediately on the Marlstone " Rockbed," which has here become a valuable iron-oret.

As we can thus, from actual observation, prove the south-easterly thinning-out of the Middle and Upper Lias, I think, bearing in mind their close relationship to the Lower Lias, that we are justified in inferring a somewhat similar thinning-away towards the Thames Valley on the part of this earliest formed member, though it has probably a more extended range. Should this supposition prove correct, the whole Liassic Series should be on the point of disappearing below Oxford.

I here wish to repeat that in the case of the Lias the line of maximum attenuation follows an E.S.E. direction. A deviation of a few degrees northward produces a considerable change in the thickness of the beds. Thus in the neighbourhood of Chipping Norton and Deddington, which are nearly due east of Cheltenham, the combined thickness of the Upper Lias and Marlstone is not less than 200 feet.

4. Inferior Oolite.-Proceeding next to the consideration of the Inferior Oolite, I take as sections for comparison those at Cleeve Cloud and Leckhampton Hill at the west, and those of the Valley of the Evenlode at the east. The formation at Cleeve Cloud is probably not less than 300 feet thick, and that at Leckhampton Hill 264 feet. This latter, ever since the original survey of Murchison $\neq$, has been regarded as the typical section of the Inferior Oolite, not only for England, but for Europe. It there consists of

* Ascertained from a measured horizontal section about to be published by the Geological Survey. Bredon Hill is the most north-westerly district where the Upper Lias exists; and its great thickness there shows the rapidity of the thinning-out towards Oxfordshire.

+ See Map of the Geological Survey, Sheet 45, S.W.

$\ddagger$ Proceedings Geol. Soe. vol. i. p. 388 . 
five well-pronounced subdivisions, the horizontal range of which throughout the Cotteswold Hills, towards the borders of Oxfordshire, I have already described in a Memoir on the district*. Without entering here into details, I will content myself with stating the following conclusions. The Pea-grit has the smallest range; next the Upper Freestone; then the Oolite-marl and Lower Freestone; and the most persistent member is the Ragstone, which, though never surpassing a thickness of 50 feet, stretches eastward into Oxfordshire, and there becomes the sole representative of the Inferior Oolite.

I find that this easterly attenuation of the Inferior Oolite is noticed by Professor J. Phillipst, and I refer to it especially as illustrating how small is the relationship between vertical depth and horizontal range. In the case of the Oolites we find that thoso beds in which there is evidence of current-action, and where the fossils are fragmentary and drifted, the horizontal area is small ; of this the Freestone Series is an example; but where the beds have been tranquilly deposited, and the fossils have been buried where they lived, the range is greater; and this is a law more or less applicable to all the sedimentary rocks of which I am treating.

In the Valley of the Evenlode wo can trace the Inforior Oolite as far as Stonosfield, and there it has a thickness of about 15 feet; but farther east, in the Valley of the Chorwell, at Rousham, it has altogether disappeared, and we find the Great Oolite resting immediately on the Uppor Lias Clay, or only separated by a thin stratum of ferruginous sand, which must be referred to the Great Oolite $\neq$.

The case of the Inferior Oolite entirely disappearing within a distance of 30 miles south-east of the point where it attains a thickness of nearly 300 feet is remarkable, because it cannot be regarded altogether in the character of a sedimentary deposit. Many of the Freestone-beds have the characters of shelly gravel, drifted by currents, and these are less persistent; others, as tho Oolite-marl and Ragstone, are partly of organic and chemical origin. It is remarkable that the line of maximum attenuation occupies a nearly parallel direction with that of the more mechanically formed rocks, such as the Lias.

5. Fuller's Earth.-Of the Fuller's Earth it is only necessary to state that it does not extend as far east as Oxfordshire. In the Cotteswold Hills we moet with it for the last time at Sherborne, near Burford $\S$. But the formation is deserving of notice as being the oldest amongst the Lower Secondary Rocks in which the direction of maximum attenuation changes from the south-east to north-east. In Somersetshire it attains a thickness of 120 feet.

6. Great Oolite.-Tho Great Oolite of Gloucester, Oxford, and

* "Geology of the Country around Cheltenham," 1857 ; Mem. Geol. Survey.

† 'Manual of Geology,' p. 303.

† Sheet 45, S.W., of the Geological Survey Map; and "Geology of the Country around Woodstock ;" Mem. Geol. Survey, p. 1t.

$\S$ "Geology of the Country around Cheltenlaain," p. 52. 
1859.]

Northamptonshire divides itself into two well-marked zones*. The Lower Zone includes the Stonesfield Slate, as well as clays, shelly oolitic freestones with current-lamination; and lastly, those thick beds of ferruginous sands which are so largely developed in Northamptonshire. The Upper Zone, on the other hand, is extremely distinct, consisting of evenly bedded limestones, weathering white, with bands of calcareous marl. The fossils of the Upper Zone are seldom fragmentary, though generally in casts, and appear to have been buried where they lived. As might be expected, the horizontal range of these two zones is very unequal, and, on the whole, they probably represent, respectively, shallow- and deep-sea conditions of the Great Oolite.

These two zones range probably from Yorkshire, and certainly from Lincolnshire, as may be gathered from the description of the Oolites of Lincolnshire by Professor Morris $\dagger$, and from thence into Northamptonshire and Oxfordshire.

The Lower Zone attains its greatest development towards the western escarpment of the Oolites of Wiltshire and the centre of the Cotteswold Hills; but eastward it dwindles down until it entirely dies out in the Valley of the Cherwell, near Woodstock.

The same south-easterly attenuation is also observable in the case of the Forest-marble, which may be considered a subformation of the Great Oolite $\neq$. Thus we have reason for concluding that under the Oxford Clay of a large portion of Northamptonshire and Oxfordshire, we should pass from the Cornbrash into the Upper Zone of the Great Oolite, and from this into the Marlstone, the intervening beds having disappeared.

From internal evidence over an extensive range, afforded by the evenly bedded limestones and marls of the Upper Zone of the Great Oolite, and from its continuity over an area extending at least from Somersetshire to Lincolnshire, combined with the fact that it furnishes no evidence of a tendency to thin away towards the southeast, I am inclined to think that this subdivision extends as far as the Palæozoic barrier of the Thames Valley, and that it is the identical part of the formation described by $\mathbf{M}$. Rozet as resting upon the Carboniferous rocks of the Bas-Boulonnais. It is the first exception to south-easterly attenuation we meet with in ascending through the Mesozoic rocks of England; and it cannot be regarded as a drifted sedimentary deposit, but as one which, like the White Chalk, was formed on the bed of a comparatively deep sea by the agency of living animals, or by the precipitation of the fine calcareous mud derived from Molluscs, Corals, and Foraminifera.

* Op. cit. p. 53.

+ Quart. Journ. Geol. Soc. vol. ix. p. 334. The beds which in Lincolnshire succeed the ferruginous limestone, considered by Professor Morris as Inferior Oolite, are "stratified sands and clays, local in their occurrence, bearing plantremains." These beds represent the "Lower Zone" of the Great Oolite, and are succeeded by marly white oolites, "indicating deeper-sea conditions," which represent the "Upper Zone."

$\ddagger$ This formation dies out in the Valley of the Cherwell, east of Woodstock. See Map of Geol. Survey, Sheet 45, S.W.; and "Geology of Woodstock," p. 24. 
With the Upper Zone of the Great Oolite, the earliest Secondary formation which does not thin away south-eastward, our investigations cease on this head, and I now propose to inquire what are the probable positions of the Palæozoic rocks under this district.

I can here avail myself of the opinions of other authors, which will render it unnecessary to dwell to a great length on this part of the subject.

\$ 4. Probable Extension of the Coal-measures from Warwickshire to the Thames Valley.-This is a subject on which it is necessary to exercise much caution, on account of the interests involved. $\mathrm{Mr}$. Godwin-Austen has already stated his opinion of the probable extension of the Coal-measures from the Coal-fields of Stafford and Warwick, to join that band which he considers to stretch along the Thames Valley under the Chalk. Even if this be the case, there may be interruptions in the form of bosses of Silurian or Cambrian rocks, and the measures themselves may be generally unproductive of valuable coal-beds.

In fact, there are evidences that the Coal-measures become attenuated towards the S.E., from phænomena observable in the Warwickshire Coal-ficld. At the southern extremity of the Coal-field, south of Bedworth, all the coal-beds, which towards Atherstone are more or less widely separated by sandstones and shales, becomo united into ono mass 30 feet thick*. At the same time the southeasterly strike of the Coal-measures and Permian rocks in the Warwickshire district shows that they tend to underlie Oxfordshire and part of Northamptonshire; and the strike of the coalbeds has been proved to continue in the same direction for a considerable distance underneath the New Red Sandstonet. Further to the south, near Coventry, the Permian Beds slightly change their strike towards the east, and, if there be any conformity between this formation and the Coal-measures, which seems to be the case in this district, the dip of tho Coal-measures must be in the direction of Oxfordshire. Of course beyond this district we have no further means of judging by actual observation whether this direction of the beds continues; but it is satisfactory to find, at the last place where the Coal-formation can be seen to the S.E., the beds tending to underlie a district where we know that the superimposed formations have become greatly lessened in depth.

\$ 5. Physical Geography of the Trias.-A. Land on the North Atlantic Area.-At the close of the Permian Period, those disturbances accompanied by marine denudation ensued which changed the distribution of land and sea, and produced a high degreo of unconformity between the Permian and Triassic Rocks. Their general effect was to extend the area of sea, and to contract the land-surface, so that the British Islands presented the appearance of a small polynesia, in place of a more or less connected line of

* Geol. Survey Map, Sheet 63, S.W., and Vertical Sections, Geol. Survey, Sheet 20.

$\dagger \mathrm{As}$ I am informed by my colleague Mr. Howell. See Geol. Map, Sheets 53 , N.W.-63, S.W.; and "Geology of the Warwickshire Coal-field," 1859. 
1859.]

HULI-THINNING-OUT OF THE SECONDARY ROCKS.

coast stretching westwards, northwards, and eastwards along the margin of the Lower Permian basin. The whole of the low-lying district between the highlands of Wales and those of Cumberland was submerged, and a channel was opened for the transport of Triassic sediment by an oceanic current from the north-west, by the agency of which it wasspread over central England as long as the various kinds of sediment were capable of being mechanically suspended.

The Lower Carboniferous Range of the Penine Chain, which during the deposition of the earlier Permian strata was elevated into land, appears to have been completely submerged under the Triassic sea. This is presumed, independently of other considerations, by the fact that we find the same succession of Triassic beds on both sides of this range. In Nottinghamshire and Yorkshire, with the exception of the "Upper Mottled Sandstone," which has thinned out, we find exactly the same succession of subformations, both of the Bunter and Keuper, as in Lancashire and Cheshire. Now it will be shown presently that all the sediment has been transported from the north-west towards the east and south, so that the strata must have been deposited continuously across this portion of Northern England,--an evident proof that there was no separating barrier of land.

Thus, at Mansfield we find the following section across the Trias, in which the same subformations occur as at Chester (with the one exception), while, at the same time, the whole series is considerably lessened in thickness. The section has been drawn from the information supplied by my colleague Mr. Talbot Aveline.

Farther north, at Worksop, on the borders of Yorkshire, the succession is the same; so that we have here strong evidence, if not absolute proof, that these beds were continuous from Lancashire to Yorkshire, right across the Carboniferous Range.

The Silurian regions of Wales and Salop were also submerged and buried under

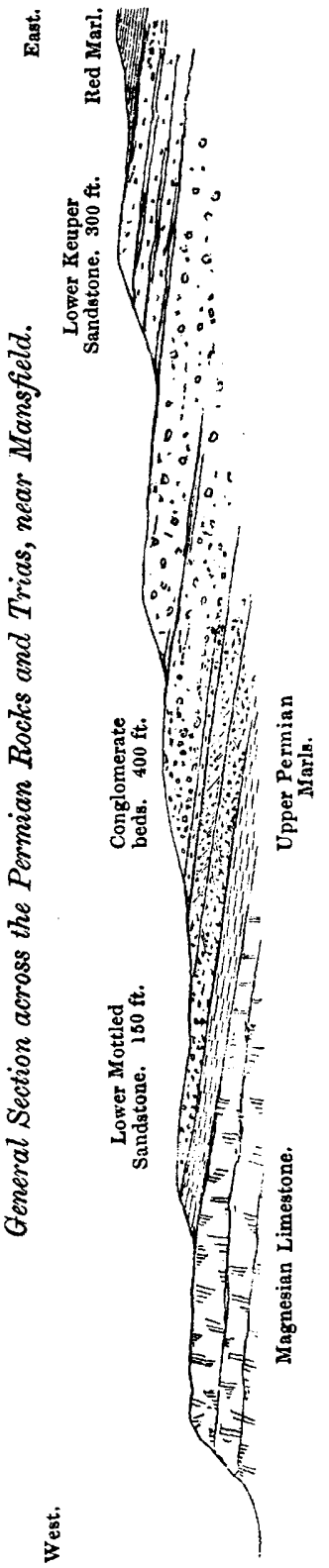
Triassic sandstones to a considerable extent 
at the close of that period. In the Valley of the Severn we find two distinct shingle-beaches, one in a position 450 feet above the base of the Bunter Sandstone, and the other about 500 feet higher. If these beds be reduced to their original horizontal position, and the whole brought below the sea-level, it would lead one to believe that all the area below 2000 feet at least was under the sea. The subsidence continued, with occasional pauses, throughout the Triassic epoch; and the extreme fineness of the sediment of the Keuper sandstones and marls proves the remoteness of the land from which it had been drifted. During the oarlier stages of the Bunter series, the siliceous sediment appears to have been drifted over the plain of Central England, through the channel formed by the mountains of Westmoreland on the north and those of Caernarvon and Denbigh on the south, filling in all the old channels and valleys; and, as the later periods of the Keuper and Lias progressed, these old headlands gradually became more contracted both in area and elevation.

At the close of the period of the Bunter Sandstone, the lowlying tracts of England were probably elevated into dry land, and remained so during the deposition of the Muschelkalk in Germany. I have arrived at this conclusion from the following considerations.

B. Subaërial conditions during the formation of the German Muschelkalk.-The base of the Keuper is almost invariably a breccia or conglomerate, the pebbles of which can be identified with those Palæozoic formations in the neighbourhood which at the close of tho Bunter period formed the coast. This breccia is, in fact, a shingle-beach; and, if we suppose the flat tracts of the Bunter to have been re-submerged at the commencement of the Keuper period, such a shingle-bed would be the inevitable result of the waves acting along a newly formed, and sometimes a bold, line of coast. Shallow seas and intertidal conditions prevailed throughout the higher stages of the Lower Keuper Sandstone; for we frequently find the footprints of Reptiles, sun-cracks, and rain-prints, showing that during the ebb of the tide the sea-bed was left dry.

C. Unconformity of the Keuper and Bunter.-There are evidences which appear to me irresistible that the strata of the Bunter and Keuper are unconformable. I have already shown the probability of this being the case in Germany, from the occurrence of pebbles of Bunter Sandstone in the Lower Keuper Sandstone of the Odenwald*, and the evidences in this country are equally strong. In the district of Alton, in Staffordshire, the base of the Keuper is formed of a white conglomeratic sandstone, resting on red shale; and its pebbles can only be referred to the reconstructed materials of the Bunter. They consist of the well-known, rounded, and coloured quartz of which we have no examples in England except from the conglomerate-beds of that formation. The Bunter conglomerates climb up the flanks of the Carboniferous rocks of Derbyshire; and, if this be the corroct interpretation of their reappearance, they have

* Quart. Journ. Geol. Soc. vol. xiv. p. 224. 
1859.] HULI-THINNING-OUT OF THE SECONDARY ROCKS.

been elevated into a marginal coast at the commencement of the Keuper period; and this would have necessarily produced a certain degree of unconformity between these two formations of the Triassic Series.

The relative position of the Bunter and Keuper in Leicestershire appears to afford evidence of unconformity. The conglomerate-beds of the Bunter are confined to the western and northern portions of the Ashby-de-la-Zouch Coal-field, where they attain a thickness of 200 or 300 feet. Along a line passing N.E. and S.W. through Moira they terminate abruptly; and east of this line we find the Lower Keuper Sandstone resting immediately on the Coal-measures. These conditions would seem to indicate,-first, that after the deposition of the conglomerates certain disturbances had occurred, elevating the south-eastern districts, and thus causing the denudation of the conglomerates from off that area; and, secondly, that, after these disturbances (involving, of course, an unconformity), the beds of the Keuper had been deposited where we find them, resting on the conglomerates of the Bunter in one direction and on the Coalmeasures in the other.

In Lancashire, near Ormskirk, there is a section showing the superposition of these formations, in which the appearance of unconformity is of so satisfactory a nature that it elicited the assent of such a cautious observer as Professor Ramsay. As the geology of this district has not yet been published by the Geological Survey, I do not feel at liberty to describe this section, but will only add that it is seldom that a more evident case of unconformity is laid open to view.

In thus stating my conviction that these formations are unconformable, I by no means wish to assert that the non-parallelism of the beds is ever very great; it is only sufficient to prove that disturbances and denudation have intervened between the two periods one effect of which was to place the bed of the Bunter Sandstone sea beyond the reach of marine deposition, and thus account for the entire absence of the Muschelkalk in England.

I shall close this subject, which I feel I have very imperfectly treated, with one more remark. It is scarcely possible to estimate the advantage, both to science and to civilization, which has resulted from the present configuration of the Mesozoic rocks of England. Keeping in mind the tendency which they exhibit to thin away towards the south-east, it is evident that, with their present strike and inclination, they are presented to us in succession along lines of fullest development. In order to estimate this more fully, we have only to reflect how dwarfish would have been the ascending series of formations, had they been upheaved along an axis coinciding with the present escarpment of the Chalk from Reading to the German Ocean. Such an arrangement would also have shut out all hope of reaching coal in the central counties, as the Carboniferous rocks would have been covered by the newer formations over the regions of their greatest vertical thickness. 
D. Causes of Variations in the Persistency of Strata.-The facts here stated regarding the thinning-away of the various kinds of strata bear out in a remarkable manner the views laid down by Sir C. Lyell in his 'Principles of Geology.' When rivers carry down to the sea fragmentary rocks, sands, and mud, of various degrees of coarseness, these materials are brought within reach of marine currents, and are by their means spread over the bed of the ocean. The larger fragments are the first to become imbedded; while the more minute particles of sand or clay are carried to great distances out to sea, and slowly sink to the bottom, forming shales and clays, like those of the Red Marl, and Lias. Of these phænomena, the Triassic group produces examples. In Cheshire, where that formation is most fully developed, the Bunter and Keuper are of nearly equal thickness; but we have seen that the beds of the Bunter, which are formed of siliceous particles, more or less coarse and of a rather high specific gravity, do not reach as far to the south-east (that is, out to sea) as the eastern borders of Leicestershire and Warwickshire, where the fine muddy strata of the Keuper are still 500 feet in depth. The case is further illustrated when we compare the limited range of the breccias, or shingle-beaches, with the other beds of the Trias. These are never found to extend far from their parent coast-lines.

In observing individual beds also, we find a marked connexion between horizontal area and tranquillity of deposition. Those strata exhibiting the agency of local marine currents, which have produced the phrnomena of false-bedding, are invariably inconstant, and, as it were, short-lived; while the evenly bedded layers, in which the fossils (in the case of fossil-bearing rocks) are entire, have much wider ranges. As points of comparison, we may placo on the ono side the two Mottled Sandstones of the Bunter and the shelly Freestones of the Inferior and Great Oolites, and on the other the Lower Keuper Sandstones, the Ragstones of the Inferior Oolite, the Upper Zone of the Great Oolito, and the Cornbrash.

\$ 6. Apparent South-easterly Attenuation of Carboniferous Series.-I believe that the conclusions here stated regarding the south-easterly attenuation of the Lower Mesozoic rocks are applicable, to some extent, to the Carboniferous rocks of Britain. The Lower Carboniferous rocks are more largely developed in Scotland than in the North of England; and my colleague Mr. Geikie informs me that the sandstones and shales of the Lothians evince a marked tendency to become thicker towards the northwest.

Professor Phillips* appears to have arrived at a similar conclusion with respect to the "Yordale Rocks" of Yorkshire; and he has shown how the sandstones, shales, and other sedimentary strata thicken towards the north-west; while the organically formed limestones appear in greatest force in an opposite direction. I have already alluded to the example in the case of the Warwickshire Coal-

* Geology of Yorkshire, p. 176. See also Explanation of the Horizontal Sections of the Geological Survey, Sheet 45. 
field ; and a still more remarkable one occurs in South Staffordshire, where the "Main Coal" of Dudley, 10 yards thick, becomes split up into several seams at the northern part of the coal-field, and separated by sandstones, shales, and clays, altogether attaining a thickness of 300 feet. This fact has been demonstrated by $\mathbf{M r}$. Jukes*, who remarks upon the great persistency of the coal-beds as compared with the inorganic materials. The Yordale series of Lancashire and North Staffordshire are enormously developed in comparison with their equivalents in Leicestershire and Warwickshire. With all these facts in view, it is much to be feared that the Carboniferous Series generally becomes greatly reduced, and probably much less productive of coal, under the districts of Oxfordshire and Northamptonshire.

$\mathrm{Mr}$. Sorby $\dagger$ has also carried on a series of investigations on the currents of these ancient seas, as indicated by the various phrnomena of stratification. It is probable that, when completed, these will lead to results of the highest interest in throwing light upon the physical geography of past times. In the meantime Mr. Sorby appears to have arrived at the conclusion, that the drifting of sediment has been from the N.W. in the case of the Carboniferous group; while tidal currents ebbed and flowed in N.E. and S.W. directions throughout parts of the Permian and Oolitic periods ł. All these phænomena point to the existence of a continent, or at least of an extensive tract of land, throughout the Carboniferous, Permian, and Lower Secondary Periods in the region now occupied by the North Atlantic Ocean.

Accepting, then, the conclusions of Mr. Godwin-Austen, that a band of Coal-measures stretches along the Thames Valley, thrown off on the north side of the Old Palæozoic Axis, it is not improbable that the formation extends, with perhaps occasional interruptions, into the central counties; but I have already hinted at the probability that, as a coal-producing set of rocks, it has become deteriorated in its extension southwards (page 74).

With regard to the formations which may be inferred to lie above the Coal-measures in Oxfordshire and Northamptonshire, it is probable we should find the following ascending series:-

1st. The Lower Permian rocks, of considerable depth northward, but diminishing in thickness towards the escarpment of the Chalk.

2nd. Above the Permian beds, we should find no Bunter Sandstone, but only the Keuper Marls, greatly diminished in thickness.

3rd. Next the Lower Lias, also greatly reduced and thinning away towards the Chalk-escarpment. If the Marlstone and Upper Lias were found to exist, it would only be as mere traces, and these would be immediately superimposed by the Upper Zone, or " White Limestones" of the Great Oolite.

A vertical section under Oxford would probably present the following descending series:-

* South Staffordshire Coal-field: Mem. Geol. Survey.

+ See Papers in the Edin. Phil. Journal, New Series.

\$ See 'Siluria,' 3rd edit., Appendix. 
Formations present.

Oxford Clay

Cornbrash

Great Oolite (Upper Zone) ...... 200

Lower Lias ....................... 200?

Red Marl (Keuper) .............. 200?

Lower Permian Beds ............ ?

Coal-measures

feet.
Formations absent.

feet. Forest Marble (greatest thickness) 150

Great Oolite (Lower Zone) ...... 100

Fuller's Earth …................ 200

Inferior Oolite .................. 270

Sands ................................... 150

Upper Lias Clay.................. 400

Marlstone ? ........................ 240

Lower Keuper Sandstone ......... 450

Bunter Sandstone ................2150

\$ 7. General Conclusions.-From the foregoing considerations the following conclusions may be drawn :-

1st. That during the deposition of the Upper Palæozoic and Lower Mosozoic Rocks an extensive tract of land existed to the north-west of the British Isles, which afforded the materials of which these rocks are composed; and it is probable that this region embraced the western isles and const of Scotland.

2nd. That the Lower Permian Rocks were deposited in a channel, of which we can trace approximately the borders to the west and north-east; and that this group attains its maximum dovelopment along a band of country stretching west and east, from the southern borders of Salop, across Staffordshire to Warwickshire.

3rd. That at the close of the Permian Period there ensued considerablo changes in the distribution of land and sea, involving a large increase in tho latter. That a highway was opened between North Wales and Westmorcland, along which the sediment for the formation of the Lower Secondary rocks was transported by an occanic current and spread over tho plains of England, filling up old Palocozoic valleys.

4th. That all the Lower Secondary formations docrease in thickness, and actually die out towards the south-east; that this attenuation is due to the increase of distance from the sourees of supply, and the consequent failure of sedimentary materials which havo come from land occupying the region of the North Atlantic.

5 th. That there probably exists a tract of Coal-measures stretching from the southern borders of the Staffordshire and Warwickshiro Coal-fields towards the Thames Valley, as previously surmised by Mr. Godwin-Austen, but that there is reason to fear that the whole formation becomos debased and less likely to contain valuable beds of coal.

6 . That the depth to the Coal-measures under parts of Oxfordshire and Northamptonshire cannot, in consequence of the thinningout of the Lower Secondary Rocks (Inferior Oolite, Lias, and Trias), be considered as beyond the reach of mining enterprise; but that the thickness of the interposed Permian rocks and the economical value of tho coal-beds are points of uncertainty, which are likely to be solved only by actual experiment. 


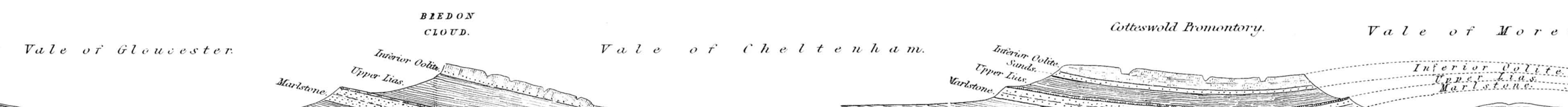

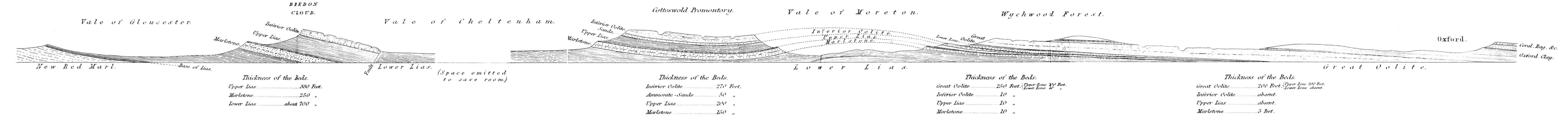

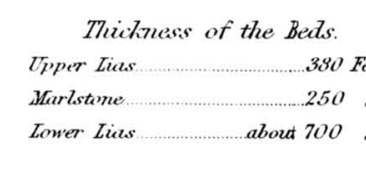

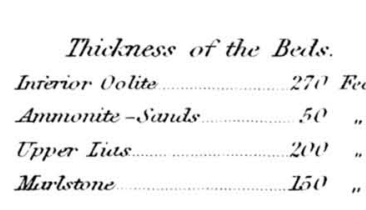

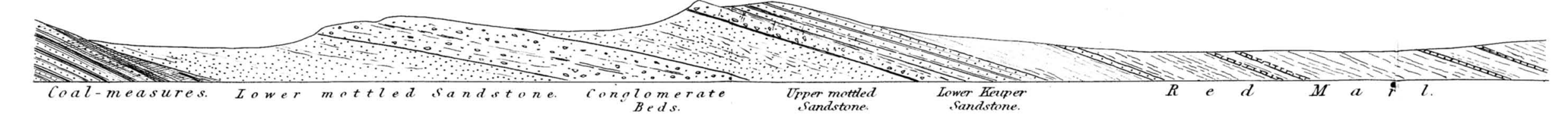

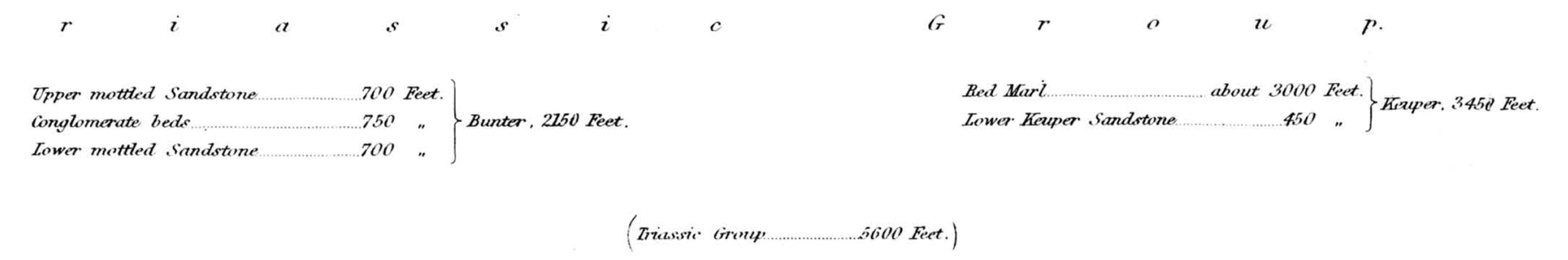

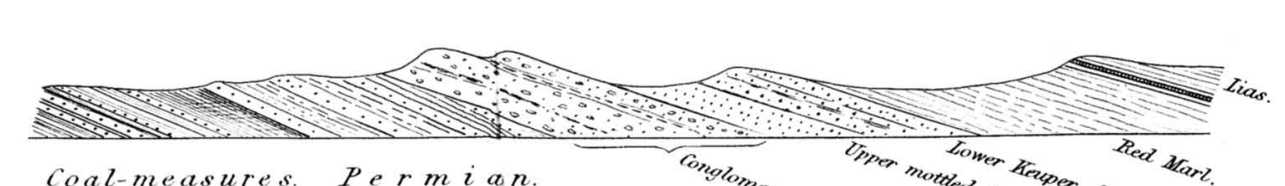

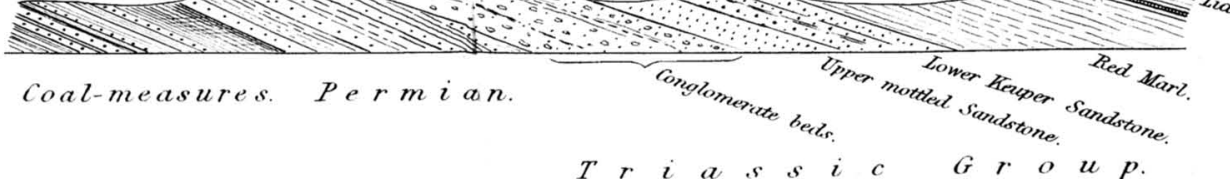

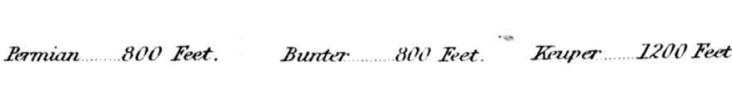

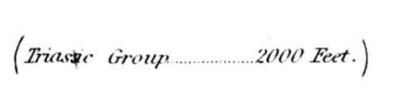


1859.] HULR-THINNING-OUT OF THE SECONDARY BOCKS.

\section{EXPLANATION OF PLATE IV.}

The sections in Plate IV. are intended to illustrate the thinning-out towards the South-east (and, per contra, the thickening towards the North-west) of all the formations from the base of the Great Oolite down to that of the Trias. Though founded on actual admeasurement of the strats, the sections are not drawn to any true horizontal scale.

Fig. 1 shows the thinning-away of the Liassic and Oolitic strata, along a line drawn from the banks of the Severn, near its junction with the Avon, across Bredon Hill, the Vale of Cheltenham, the Cotteswold promontory, and Vale of Moreton, to the hills of Coral-rag above Oxford. The line runs W.N.W. and E.S.E. By comparing the thickness of the formations (as given in the figures immediately under the sections) where they are capable of being measured, it will be seen how they all tend to thin away towards Oxford. The whole of the Inferior Oolite is not present on Bredon Cloud, so that its thickness cannot be compared with that of its representative on the Cotteswold Hills; but in the Valley of the Cherwell, near Woodstock, the formatiou has altogether disappeared. The Upper Zone of the Great Oolite, however, evinces no tendency to thin away in any direction.

Figs. 2, 3, and 4 may be considered as one intermupted section, and are to illustrate the same principles in the case of the Triassic racks. The direction of the section is along a line drawn from the mouth of the Mersey to that of the Thames; and in each the thickness of the formation with its groups is shown as it occurs in Cheshire, Staffordshire, and East Warwickshire. It will bo observed that, while the Bunter Sandstone attains in Cheshire and Lancashire the surprising thickness of 2000 feet and upwards, in Staffordshire it has considerably lessened, and dies out before reaching the neighbourhood of Coventry.

The Keuper series in Cheshire is upwards of 3000 feet thick; in Staffordshire it is only 1200; and in East Warwick about 600 . The section is continued through the Liassic and Oolitic formstions into Oxfordshire.

These sections also show the manner of the distribution of the Lower Permian rocks along the same line of country. This formation becomes more fully developed in Warwickshire than in Staffordshire, and in this latter county more than in Cheshire; proving the remarkable change which ensued at the close of the Palreozoic period in the physical circumstances under which the rocks of the two great epochs were deposited. 